\title{
A fizikai aktivitás hatásai az időskori kognitív múködésre
}

\author{
Mile Marianna ${ }^{1}$. Tatai Csilla ${ }^{2}$

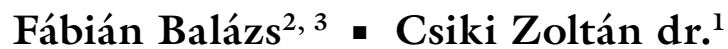 \\ ${ }^{1}$ Debreceni Egyetem, Általános Orvostudományi Kar, Belgyógyászati Intézet, Debrecen \\ ${ }^{2}$ Debreceni Egyetem, Népegészségügyi Kar, Magatartástudományi Intézet, Debrecen \\ ${ }^{3}$ Debreceni Egyetem, Egészségtudományok Doktori Iskola, Debrecen
}

\begin{abstract}
Az időskorú személyek száma és társadalmi aránya folyamatosan növekszik, különös tekintettel az európai országokra, de ez a világ teljes népességére is vonatkozik. Az idősebb korosztály arányának további gyarapodásával az öregedő társadalom egészségi állapotának romlása okozta szociális és egészségügyi szférákat érintő többletköltségek is egyre tovább emelkednek. Az öregedés folyamata az egészségi állapot romlásának és az általános funkcióképesség csökkenésének testi vonatkozásain túl a mentális, kognitív teljesítmény romlásával is együtt jár, ami tovább nehezíti az idős korosztály mindennapjait. Ezek a tények felhívják a figyelmet a beavatkozás megjósolható szükségességére. A korábbi vizsgálati eredmények szerint a fizikai aktivitás alkalmas lehet a kognitív múködés javítására, a romlás megállítására és megelőzésére. A jelen közleményben áttekintjük a fizikai aktivitásnak a kognitív múködésre kifejtett hatásait mind általánosságban, mind pedig három specifikus mozgásforma tekintetében, illetve a további aktuális kutatási irányokat is felvázoljuk

Orv Hetil. 2020; 161(5): 163-168.
\end{abstract}

Kulcsszavak: fizikai aktivitás, kognitív múködés, időskor

\section{Effects of physical activity on cognitive function in older adults}

There is an absolute and relative increase in the proportion of the elderly population especially in the European countries, but this tendency can be also observed universally. By the continuous increase of the proportion of the elderly population, the medical and social related financial burdens are also increasing because of the significant decrease in health condition among older adults. The process of aging includes not only the constant decline of the general health condition and daily functioning, but also includes the decrease of the mental and cognitive performance, which further impairs the everyday life of the older adults. These findings warrant the necessity of preventive interventions in the future. According to previous findings, physical activity can be used to improve cognitive functioning and prevent further decline. In this article we provide a brief review of the literature on physical activity effects on cognition in general and with referring to three different specific forms of physical exercise; moreover, briefly discuss the important future directions of research.

Keywords: physical activity, cognitive function, elderly

Mile M, Tatai Cs, Fábián B, Csiki Z. [Effects of physical activity on cognitive function in older adults]. Orv Hetil. 2020; 161(5): 163-168.

(Beérkezett: 2019. szeptember 23.; elfogadva: 2019. október 31.)

\section{Rövidítés}

WHO $=$ (World Health Organization $)$ Egészségügyi Világszervezet

Az idős korosztály a leggyorsabban gyarapodó réteg a mai társadalomban. Az Egyesült Államokban 1980 és 2010 között a 65 év felettiek aránya 11\%-ról 13\%-ra emelkedett, és 2030-ig ez az arány előreláthatóan el fogja érni a 19-20\%-ot is [1]. Hasonló változások figyelhetők meg Magyarországon is. A 60 év felettiek arányát tekintve a lakosságnak 2001-ben az ötöde, a 2011. évi népszámlálás alkalmával pedig közel a negyede számított idősnek. A társadalom korösszetételének változását jelzi az öregedési mutató, amely a gyermekkorúak és az időskorúak egymáshoz viszonyított arányát írja le. Míg 100 
gyermekkorúra 2001-ben 123, addig 201 1-ben már 161 időskorú jutott [2]. A Föld teljes lakosságát tekintve, a WHO becslései szerint 2000-ben 10\%, vagyis megközelítőleg 600 millió ember volt 60 évnél idősebb, és arra lehet számítani, hogy 2025-ig ez a szám elérheti az 1,2 milliárdot, illetve 2050-ig az 1,9 milliárdot [3]. Noha örvendetes, hogy ezen változások egyik fó oka a születéskor várható élettartam növekedése [4], az idősek számának és arányának emelkedésével együtt növekednek a szociális-egészségügyi ellátási költségek is az egyre gyakoribb testi panaszok és a szellemi hanyatlás miatt.

Az öregedés természetes folyamata múködésbeli, pszichés és biokémiai változásokat foglal magában, amelyek csökkentik az egyénnek a mindennapos tevékenységek elvégzéséhez szükséges képességeit [5]. A 60 év felettiek csaknem több mint 50\%-a szenved krónikus egészségügyi problémáktól, és ezek prevalenciája és súlyossága emelkedik az évek előrehaladtával [6]. A következő évtizedekben a 65 év felettiek arányának további növekedésével együtt jár az életkorral összefüggő betegségek és rendellenességek arányának növekedése is, beleértve az életkorspecifikus szellemi leépülést, az Alzheimer-kórt és más típusú dementiákat is [7]. Ezért fokozott igény van arra, hogy azonosítsuk azokat a tényezőket, amelyek késleltethetik, megállithatják ezeket a folyamatokat, s védelmet nyújtanak többek között a kognitív hanyatlás ellen is, vagy akár képesek azt visszafordítani [8]. Nagy egyéni különbségek figyelhetők meg mind a hanyatlás mértékében, mind kiterjedtségében olyan kognitív képességek esetén, mint például az epizodikus memória (a múltban megélt események felidézése), a feldolgozási sebesség (a mentális feladatok megoldásának sebessége) és a végrehajtó funkciók (a viselkedés szervezését ellátó komplex mentális folyamatok), ami alapján feltételezhető, hogy bizonyos tényezők jelenléte befolyásolja a kognitív leépülés forgatókönyvét [9]. Ezek az eredmények felvetnek néhány ígéretes hipotézist azzal kapcsolatban, hogy az életkorfüggő hanyatlás nem elkerülhetetlen, és ha az abban közrejátszó tényezőket sikerül azonosítani, lehetőség nyílna a hatékonyabb prevencióra és terápiára is [10]. Az időskori rendszeres fizikai aktivitás hatásainak vizsgálata az utóbbi időben nagy tudományos figyelmet kapott, többek között a vérnyomásra, a vércukorszintre, a fizikai erônlétre, az egyensúlyi problémákra és az alvászavarokra vonatkozóan, de potenciálisan ígéretes módszernek túnt a szellemi hanyatlás kockázatának csökkentésében is.

Ebben az áttekintő közleményben bemutatjuk, hogyan kapcsolódik a fizikai aktivitás és a fittség a kognitív teljesítményhez idősebb felnőttek körében. A közleményt az alapvető fogalmak - mint a fizikai aktivitás vagy a normál kognitív deficit - ismertetésével kezdjük. Bemutatjuk azon vizsgálatok módszertani közelítéseit és eredményeit, amelyek a kognitív múködés és a fizikai aktivitás kapcsolatával foglalkoztak. Reflektálunk néhány specifikus mozgásforma hatásával kapcsolatos eredményre is, majd röviden kitérünk az időskori kognitív múködés szempontjából jelentős, egészségi állapottal kapcso- latos további tényezők szerepére is. Áttekintő tanulmányunkat az eddigi vizsgálatok korlátainak ismertetésével és a jövő kutatási irányvonalainak felvázolásával zárjuk.

\section{Fizikai aktivitás}

A rendelkezésre álló legfontosabb kutatási eredmények ismertetése előtt fontos definiálnunk néhány releváns fogalmat. A „fizikai aktivitás” általános fogalom, amely vonatkozik mind az aerob (a rendelkezésre álló nagy menynyiségú oxigén elégetésével állít elő energiát a szervezet), mind az anaerob (nem áll rendelkezésre elegendő oxigén, például ellenállóképesség-fejlesztő edzés) mozgásformákra, függetlenül azok típusától, időtartamától és gyakoriságától. Magában foglalja a mérsékelttôl az erőteljesig a strukturált aerob mozgásokat, mint például a gyors gyaloglás, tenisz, úszás, kertészkedés vagy tánc, de a legalapvetőbb mindennapos tevékenységeket is, például sétálás, lépcsőzés stb. [11]. A kognitív hanyatlásra irányuló keresztmetszeti vizsgálatokban eredetileg önkitöltős kérdőívekkel mérték a fizikai aktivitást, melyek olyan kérdések megválaszolását kívánták a kitöltóktől, mint például „Átlagosan hány háztömbnyit sétál egy nap?” [12]. Ezen önkitöltőss kérdő́ivek előnye, hogy a nagy elemszámú minta válaszait könnyen lehet adminisztrálni és értelmezni, rövid idő alatt kiértékelhetők, ugyanakkor hátrányuk, hogy a kitöltők hajlamosak lehetnek a szociális kívánatosság irányába torzítani, valamint nem feltétlenül méri megbízhatóan a napközbeni nem strukturált fizikai tevékenységeket. Számos újabb vizsgálatban objektív mérőeszközöket alkalmaztak (például gyorsulásmérőt vagy lépésszámlálót) a fizikai aktivitás és fittség mérésére. Az eredmények azt mutatták, hogy ezek az eszközök sokkal érzékenyebbek az apróbb változásokra a napközbeni fizikai aktivitás mintázatainak mérésekor, és - értelemszerúen - a vizsgálati személyek esetleges elfogultsága sem befolyásolta az eredményeket [13]. A fizikai aktivitás befolyásolja az általános fizikai fittséget, a cardiovascularis állóképességet, az izomerőt, a hajlékonyságot és a testösszetételt. A cardiovascularis kitartás egyik mutatója a maximális oxigénfelvevő kapacitás, amelyet gyakran használnak a cardiovascularis fittség javítását célzó intervenciók hatékonyságának mérésére. Ezen aerob mozgásos intervenciók során a résztvevők randomizált feltételeknek megfelelően valamilyen strukturált aerob vagy anaerob tevékenységet végeznek, gyakran a maximális oxigénfelvevő kapacitást mérve, tesztelve, hogy az intervenció hatékonyan fejleszti-e a cardiovascularis állóképességet. A legtöbb, neurokognitív kimenetelt vizsgáló mozgásos intervenció aerob mozgásformákat alkalmaz, mint például gyors gyaloglást idősebb felnőtteknél, de számos vizsgálatot - amelyeket a későbbiekben ismertetni fogunk - végeztek anaerob mozgásformával, mint például az ellenállóképesség-fejlesztő edzéssel is. Az ellenállóképesség-fejlesztő edzések vizsgálatai gyakran együttesen mérik az izomerôt (például maximális ismétlésszám) és a kitartást [14]. 


\section{Normális kognitív változások}

Ahogy az egyénen belüli kognitív funkciók, úgy az egyének között a kognitív öregedés is nagy különbözőségeket mutathat [15]. A természetes kognitív hanyatlás Salthouse és mtsai definíciója szerint nem más, mint a felnőttkorban az életkor előrehaladtával a különféle kognitív funkciók teljesítménymutatóiban bekövetkező csökkenés [16]. A fiziológiás hanyatlás számos kognitív képességet érint. Többek között ilyen az auditoros és vizuális percepció, az osztott figyelem, az emlékezet, a feldolgozási sebesség, az epizodikus memória, a végrehajtó funkciók, a számolási és számtani képességek és a fluid (folyékony) intelligencia (újszerü helyzetekben mutatott teljesítmény) [16, 17]. Ezek a normatív, az idősödéssel járó kognitív változások kifejtik hatásukat a pénzügyi készségek területén is, mégpedig a befektetések részleteire való figyelemre, a kockázatfelmérésre, más befektetési alternatívák megértésére és az általános financiális döntéshozatali képességre is [18]. Néhány longitudinális vizsgálat arra mutatott rá, hogy egyeseknél a teljesítménycsökkenés csak 60 éves kor fölött veszi kezdetét, utalva a végzettség és más életmódbeli vagy társas tényezők erős befolyásoló hatására [19, 20]. Másrészről a „kognitív pragmatika” (angolul: cognitive pragmatics; a nyelvhez kapcsolódó mentális múködések, amelyek tapasztalat-központú és kulturálisan átadódó tényszerű tudásra vonatkoznak, mint például a szókincs) vagy a „kristályos intelligencia" (angolul: crystallized intelligence; a korábban elsajátított készségek, tudás és információ öszszessége) mint a tudáson és tapasztalaton alapuló képességek nemcsak, hogy stabilnak tekinthetők, hanem fejleszthetők is időskorban. Ezért az olyan részképességek, mint a verbális ismeretek, az autobiografikus emlékezet (az önéletrajzzal kapcsolatos emlékek) vagy az érzelmi folyamatok szabályozása, képesek lehetnek ellensúlyozni az időben kevésbé stabil kognitív képességeik deficitjeit, így a kognitív múködésekben bekövetkező hanyatlást is. E kompenzatorikus lehetőségek kiaknázásával az öregedés során a normál kognitív hanyatlás csökkent hatást fejt ki a mindennapos életvezetésre [21].

\section{Fizikai aktivitás és kognitív múködés}

A fittség, a fizikai aktivitás és a kogníció vizsgálata viszszanyúlik egészen az 1970-es évekre, amikor Spirduso és Clifford [22] azt figyelték meg, hogy az idősebb sportolók szignifikánsan jobban teljesítettek egy reakcióidőt mérő feladatsorozaton, mint ülő életmódot folytató társaik, illetve teljesítményük nem különbözött jelentősen a fiatalabb (18-25 éves) felnőttekétől. A magasabb fittségi szint, a több fizikai aktivitás és a jobb kognitív teljesítmény közötti kapcsolatot mára már több tucat vizsgálat megerősítette, és a keresztmetszeti vizsgálatok metaanalízisei alátámasztották, hogy a fizikai aktivitásban való részvétel és a magasabb fittségi szint szignifikánsan magasabb kognitív teljesítménnyel jár együtt
[23]. Nagy mintaelemszámú epidemiológiai, valamint prospektív és retrospektív módszert alkalmazó kutatásokban egyaránt összefüggést mutattak ki az önbevallásos fizikai aktivitás és a dementia alacsonyabb kockázata [24] és az enyhébb kognitív károsodás között [25]. Egy 15 prospektív, longitudinális vizsgálatot feldolgozó metaanalízis szerint, melyben több mint 33000 résztvevőt követtek 1-12 évig, a nagyobb mértékú fizikai aktivitásban részt vevők esetén közel 40\%-kal csökkent a kognitív leépülés kockázata [26]. Összességében ezek a vizsgálatok meggyőzően foglalnak állást amellett, hogy a fokozott fizikai aktivitás együtt jár a kognitív hanyatlás és az Alzheimer-kór alacsonyabb kockázatával. Yaffe és mtsai [27] egészen addig elmentek a fizikai aktivitás szerepének hangsúlyozásában, hogy szerintük az Egyesült Államokban a fizikai aktivitás lehet a dementia egyetlen, legfontosabb befolyásolható protektív tényezője. A továbbiakban az aerob mozgásformákkal és az anaerob mozgásformának minősülő ellenállóképességfejlesztő edzéssel kapcsolatos eredményeket fogjuk részletesebben bemutatni. Mivel elegendő eredmény áll rendelkezésre, az aerob mozgásformák közül a jógát külön is tárgyalni fogjuk.

\section{Aerob mozgás}

Dustman és mtsai [28] négy hónapig tartó intervenciós vizsgálatukban 43 ülő életmódú, de kognitív szempontból egészséges idősebb felnőttet véletlenszerúen csoportokba osztottak. A három csoport az alábbi volt: 1) aerob edzést végző csoport, amelynek tagjai hetente három alkalommal egyórás sétát és lassú kocogást végeztek, 2) laza nyújtó gyakorlatokat végző és 3) testmozgást nem végzô kontrollcsoport. A kutatók azt találták, hogy az aerob mozgást végző csoport esetében javult a memória, a feldolgozási sebesség és a gátláskontroll (kognitív képesség, amelynek magas fokán a személy képes az ösztönös vagy szokásos reakciót késleltetni vagy gátolni), míg a másik két csoportban nem volt megfigyelhető javulás. Hasonló hatást találtak egy 124 fós, kognitív szempontból egészséges, de kevésbé edzett idősebb felnőttekből álló mintán, akik gyors gyaloglásos vagy nyújtásokat végző csoportba kerültek [29]. Hat hónap elteltével a mozgást végző csoport a kontrollcsoporthoz képest javulást mutatott a feladatok közötti kognitív váltásban, a válaszadási készségben és a gátláskontrollt mérő feladatokban. Ezzel szemben a végrehajtó funkciókat kevésbé igénybe vevő feladatokban és helyzetekben nem mutatkozott jelentős különbség a két csoport között. Kramer és mtsai mindezek alapján azt feltételezték, hogy a mozgásterápia következtében a végrehajtó funkciók javulása várható a leginkább [29]. Ezt a hipotézisüket egy metaanalízissel tesztelték, amelybe 18 randomizált, intervenciós és/ vagy kontrollcsoportot alkalmazó, a fizikai aktivitás hatását vizsgáló intervenciós kutatás eredményeit vonták be [30]. A metaanalízis eredménye szerint a gyakorlatoknak a kognitív funkciókra gyakorolt hatása mind általánosan, 
mind specifikusan megmutatkozott. Általánosságban közel minden kognitív területen javulás mutatkozott; azonban specifikusan a végrehajtó funkciók esetében jelentősebb volt a fizikai aktivitás hatása, mint a többi kognitív funkció esetén.

\section{Jóga}

Az indiai eredetû́ jóga egy ôsi védikus tudomány- és gyakorlati rendszer, amelyet manapság egyre gyakrabban alkalmaznak a kiegészítő és alternatív medicina keretein belül [31]. A hatha jóga a legismertebb altípus, amely a testtartásokra (ún. ászanákra) helyezi a hangsúlyt, melyek közé időnként légző- és ritkábban meditációs gyakorlatokat is iktat. Az Egyesült Államokban a jóga növekvő népszerúségnek örvend: a jógát gyakorló emberek száma megkétszereződött az elmúlt 10 évben [32]. Az eredmények szerint a jógával való elégedettség magas [33], és az idősebbek hangulatjavító hatású gyógymódként tekintenek rá [34]. Az általános jóllét fenntartásában és a betegségmegelőzésben betöltött szerepe mellett a jóga a kognitív funkciókra is jótékony hatással van. Hariprasad és mtsai [35] 87 fó, nem demens, öregotthonban élő időssel végeztek egy randomizált vizsgálatot. Kimutatták, hogy hat hónap jógázás (testtartások, légzőgyakorlatok és meditáció alkalmazásával) szignifikáns javulást eredményezett a hosszú és rövid távú verbális emlékezetben (nyelvi tartalmak előhívása), a hosszú távú memóriában (időben távoli események vagy szerzett ismeretek felidézése), a figyelemben és a feldolgozási sebességben is. Egy frissen elvégzett metaanalízis eredményei szerint a jóga szignifikáns hatást gyakorol egészséges felnőtteknél a kognitív múködés több területére, köztük a figyelemre, a feldolgozási sebességre, a végrehajtó funkciókra és a memóriára is [36].

\section{Ellenállóképesség-fejlesztő edzés}

Az ellenállóképesség-fejlesztő vagy ellenállásos edzés (angolul: resistance-exercise training, resistance exercise, resistance training vagy strength training) olyan mozgásforma, amely specifikus vázizomcsoportok akaratlagos összehúzódását stimulálja valamilyen külső ellenállással vagy erőhatással szemben [37]. Több vizsgálat is arról számolt be, hogy az ellenállóképesség-fejlesztő edzés önmagában és más mozgásformákkal együttesen alkalmazva is kedvező hatással van számos kognitív mutatóra kognitív deficitekkel nem rendelkező idősek körében, akiknél az edzések egyértelmú dózis-válasz hatást mutatnak [38]. Az ellenállóképesség-fejlesztő edzés pozitív hatást gyakorolt olyan kognitív múködésekre, mint a figyelem, a memória, a feldolgozási sebesség és a végrehajtó funkciók [39]. Az erônléti edzések jótékony hatását képalkotó vizsgálatok is megerősítették [40,41].

\section{Az időskori kognícióval összefüggő további tényezők}

Áttekintő cikkünkben a fizikai aktivitás hatásaira mint egy, a késői felnőtttkorban a kognitív és az agyi múköóseket befolyásoló fontos egészségviselkedésre fókuszáltunk. Mindemellett fontosnak tartjuk kiemelni, hogy más kapcsolódó tényezôknek szintén fontos szerepük van a kognitív és az agyi múködésben a késői felnőtttkorban, amelyeket nem érdemes figyelmen kívül hagyni a fizikai aktivitás hatásainak áttekintésekor. Például számottevő bizonyíték áll rendelkezésre már arról, hogy a magas vérnyomás gyengébb kognitív múködésekkel, a fehérállomány jelentősebb károsodásával és a dementia emelkedett kockázatával jár együtt $[42,43]$. Az elhízás szintén fontos, a dementia kialakulásának kockázatát növelő egészségtényező [44], amely csökkent agyi fehérállományi integritással [45] és az agyi prefrontális hálózatok csökkent múködésével jár együtt [46]. Hasonlóan, számos tanulmány vizsgálta a metabolikus szindróma hatását a kognitív múköóésre. A metabolikus szindróma a cardiovascularis betegségek kialakulásának kockázatát növelő anyagcsere-folyamatok egy gyújtő́csoportja, amelyben sok esetben egyidejúleg van jelen a 2-típusú cukorbetegség, az elhízás, a magas vérnyomás és az inzulinrezisztencia [47]. Több vizsgálat kimutatta a metabolikus szindróma összefüggését a csökkent agytérfogattal [48] és a megromlott kognitív múködéssel [49] a középső és késôi életévekre vonatkozólag. Mindezek alapján a cardiovascularis és a metabolikus rizikófaktorok jelentós szerepet töltenek be a kognitív és az agyi egészségben és a dementia kockázatában az életkor előrehaladtával. Így azt mondhatjuk, hogy a fizikai aktivitás szorgalmazása a szív- és érrendszeri egészségre kifejtett hatásain keresztül is hozzájárulhat az egészséges, időskori kognitív múködéshez.

\section{Következtetések}

Az eddigi eredmények alapján a keresztmetszeti vizsgálatok egyértelmúen bizonyították a kapcsolatot a magasabb fittségi mutatók, a fizikai aktivitás és a jobb kognitív múködés között időskorban. Bár a randomizált kontrollált vizsgálatok száma még csekély, a jelenleg rendelkezésre állók alátámasztják a keresztmetszeti vizsgálatok eredményeit; kimutatták, hogy a fizikai aktivitás növelését alkalmazó beavatkozások képesek a kognitív funkciók javítására. Összefoglalva azt mondhatjuk, hogy az epidemiológiai és kognitív vizsgálatok számos meggyőző eredménnyel szolgálnak a mozgásnak az agyi egészségre és múködésre gyakorolt pozitív hatásairól. Az aerob testmozgás, különös tekintettel a jógára, és az ellenállóképesség-fejlesztő edzés hatékony lehet az idősebb korosztály körében a kognitív deficitek megelőzésében, illetve az enyhe kognitív deficittel, dementiával vagy Alzheimer-kórral rendelkezők esetén is.

$\mathrm{Az}$ ígéretes eredmények ellenére sok módszertani nehézség terheli a kutatási területet. Számos, önbevalláson 
alapuló és objektív eszközöket használó módszert alkalmaztak, így az eredmények összehasonlítása, általánosíthatósága és a következtetések bizonyossága megkérdőjelezhető. Szükséges lenne egy standard vagy ahhoz közelítő mérési módszertan kialakítása. A vizsgálatok további korlátja volt az alkalmazott minták nagy változatossága. Az idősödő népesség esetén az eredmények általánosításában torzításokkal számolhatunk, mivel a kognitív múködés és/vagy a tanulási képesség átlagos színvonala valószínúleg felülértékelt, hiszen az alacsonyabb színvonalú kognitív múködést mutató egyének kisebb valószínúséggel vesznek részt egy ilyen vizsgálatban, mint jobban funkcionáló társaik. Több mozgásforma esetén, mint például a tánc [50] vagy a tajcsi [51], ellentmondásos eredmények születtek a hatékonyságot illetően, amelyeket a jövőben szintén érdemes lehet tisztázni randomizált, kontrollált vizsgálatokkal. A további vizsgálatoknak nagyobb hangsúlyt kellene fektetniük arra, hogy pontosan milyen típusú, mennyiségü, gyakoriságú és időtartamú mozgásforma vagy mozgásformák a leghatásosabbak a kognitív múködések fejlesztésében. Ehhez azonban nagyobb következetesség és az alkalmazott intervenció pontosabb, részletesebb ismertetése lenne szükséges az alábbiak tekintetében: az alkalmazott módszer (például jóga) pontos típusa, az intervenció elemei (az adott gyakorlatok), az intervenció hossza, a dózis (a gyakorlás időtartama és gyakorisága), az oktatók végzettsége és kiválasztásuk módja.

Összefoglaló tanulmányunkban felhívjuk a figyelmet arra, hogy a rendszeres fizikai aktivitás - azon túl, hogy általánosságban véve segíti az egészség fenntartását - az agyi-kognitív folyamatok épsége megőrzésének, valamint időskori javításának egy reményteljes módszere is lehet. Mindezek alapján különösen fontos az időskorú betegek ellátásában és gondozásában részt vevő egészségügyi szakemberek figyelmének felhívása arra, hogy a rendszeres testmozgás javíthatja, illetve kompenzálhatja az agyban és a kognícióban létrejövő életkori hanyatlást, és ezáltal segíthet abban, hogy az idősek hosszabb ideig független és teljes életet élhessenek.

Anyagi támogatás: A közlemény megírása anyagi támogatásban nem részesült.

Szerzői munkamegosztás: M. M.: Részvétel a háttérirodalom összegyújtésében, a tanulmány végleges formájának kialakításában. F. B.: A tanulmány kiegészítése módszertani szempontokkal, stilisztikai véleményezés. T. Cs.: A fordítási munkákban való részvétel, a kézirat vázlatos megszövegezése. Cs. Z.: Szakértői részvétel az eredmények összegzésében és a témafókusz kialakításában, szakmai véleményezés. A cikk végleges változatát valamennyi szerző elolvasta és jóváhagyta.

Érdekeltségek: A szerzőknek nincsenek érdekeltségeik.

\section{Irodalom}

[1] Barbieri M, Ouellette N. The demography of Canada and the United States from the 1980s to the 2000s: a summary of changes and a statistical assessment. Population (Engl Ed). 2012; 67: 177-280.

[2] Hungarian Central Statistical Office. The growing part of population - The characteristics of elderly population. [Központi Statisztikai Hivatal. A népesség gyarapodó rétege - Az időskorúak jellemzői.] Központi Statisztikai Hivatal, Budapest, 2014. [Hungarian]

[3] Hutton D. Older people in emergencies: considerations for action and policy development. World Health Organization, Geneva, 2008.

[4] Csaba Gy. Possibilities for prolonging human lifespan. [Az emberi élettartam megnövelésének lehetőségei.] Orv Hetil. 2018; 159: 1655-1663. [Hungarian]

[5] Ramos-Jiménez A, Hernández-Torres RP, Wall-Medrano A, et al. Cardiovascular and metabolic effects of intensive Hatha Yoga training in middle-aged and older women from northern Mexico. Int J Yoga 2009; 2: 49-54.

[6] Hariprasad VR, Sivakumar PT, Koparde V, et al. Effects of yoga intervention on sleep and quality-of-life in elderly: a randomized controlled trial. Indian J Psychiatry 2013; 55(Suppl 3): S364S368.

[7] Alzheimer's Association. 2010 Alzheimer's disease facts and fig ures. Alzheimers Dement. 2010; 6: 158-194.

[8] Jack CR Jr, Holtzman DM. Biomarker modeling of Alzheimer's disease. Neuron 2013; 80: 1347-1358.

[9] Salthouse TA. Does the meaning of neurocognitive change change with age? Neuropsychology 2010; 24: 273-278.

[10] Erickson K, Gildengers AG, Butters MA. Physical activity and brain plasticity in late adulthood. Dialogues Clin Neurosci. 2013; 15: 99-108.

[11] Caspersen C, Powell KE, Christenson GM. Physical activity, exercise, and physical fitness: definitions and distinctions for healthrelated research. Public Health Rep. 1985; 100: 126-131.

[12] Erickson KI, Raji CA, Lopez OL, et al. Physical activity predicts gray matter volume in late adulthood: the Cardiovascular Health Study. Neurology 2010; 75: 1415-1422.

[13] Gow AJ, Bastin ME, Muñoz Maniega S, et al. Neuroprotective lifestyles and the aging brain: activity, atrophy, and white matter integrity. Neurology 2012; 79: 1802-1808.

[14] Fitzgerald MD, Tanaka H, Tran ZV, et al. Age-related declines in maximal aerobic capacity in regularly exercising vs. sedentary women: a meta-analysis. J Appl Physiol. 1997; 83: 160-165.

[15] Lövdén M, Bäckman L, Lindenberger U, et al. A theoretical framework for the study of adult cognitive plasticity. Psychol Bull. 2010; 136: 659-676.

[16] Salthouse TA. Theoretical perspectives on cognitive aging. Lawrence Erlbaum Associates, Hillsdale, NJ, 1991.

[17] Glisky EL. Changes in cognitive function in human aging. In: Riddle DR. (ed.) Brain aging: models, methods, and mechanisms. CRC Press, Boca Raton, FL, 2007; pp. 3-20.

[18] Laibson D. Age of reason. Paper presented at the 23rd annual Morningstar Investment Conference, Chicago, IL, 2011.

[19] Hedden T, Gabrieli JD. Insights into the ageing mind: a view from cognitive neuroscience. Nat Rev Neurosci. 2004; 5: 87-96.

[20] Rönnlund M, Nyberg L, Bäckman L, et al. Stability, growth, and decline in adult life span development of declarative memory: cross-sectional and longitudinal data from a population-based study. Psychol Aging 2005; 20: 3-18.

[21] Harada CN, Natelson Love MC, Triebel KL. Normal cognitive aging. Clin Geriatr Med. 2013; 29: 737-752.

[22] Spirduso WW, Clifford P. Replication of age and physical activity effects on reaction and movement time. J Gerontol. 1978; 33: 26-30. 
[23] Etnier JL, Nowell PM, Landers DM, et al. A meta-regression to examine the relationship between aerobic fitness and cognitive performance. Brain Res Rev. 2006; 52: 119-130.

[24] Middleton LE, Barnes DE, Lui LY, et al. Physical activity over the life course and its association with cognitive performance and impairment in old age. J Am Geriatr Soc. 2010; 58: 1322-1326.

[25] Grande G, Vanacore N, Maggiore L, et al. Physical activity reduces the risk of dementia in mild cognitive impairment subjects: a cohort study. J Alzheimers Dis. 2014; 39: 833-839.

[26] Sofi F, Valecchi D, Bacci D, et al. Physical activity and risk of cognitive decline: a meta-analysis of prospective studies. J Intern Med. 2011; 269: 107-117.

[27] Yaffe K, Barnes D, Nevitt M, et al. A prospective study of physical activity and cognitive decline in elderly women. Women who walk. Arch Intern Med. 2001; 161: 1703-1708.

[28] Dustman RE, Ruhling RO, Russell EM, et al. Aerobic exercise training and improved neuropsychological function of older individuals. Neurobiol Aging 1984; 5: 35-42.

[29] Kramer AF, Hahn S, Cohen NJ, et al. Ageing, fitness and neurocognitive function. Nature 1999; 400: 418-419.

[30] Colcombe SJ, Kramer AF, Erickson KI, et al. Cardiovascular fitness, cortical plasticity, and aging. Proc Natl Acad Sci USA 2004; 101: 3316-3321.

[31] Singh S, Kyizom T, Singh KP, et al. Influence of pranayamas and yoga-asanas on serum insulin, blood glucose and lipid profile in type 2 diabetes. Indian J Clin Biochem. 2008; 23: 365-368.

[32] Clarke TC, Black LI, Stussman BJ, et al. Trends in the use of complementary health approaches among adults: United States, 2002-2012. Natl Health Stat Report 2015; 79: 1-16.

[33] Eyre HA, Siddarth P, Acevedo B, et al. A randomized controlled trial of Kundalini yoga in mild cognitive impairment. Int Psychogeriatr. $2017 ; 29$ : 557-567.

[34] Ayers CR, Sorrell JT, Thorp SR, et al. Evidence-based psychological treatments for late-life anxiety. Psychol Aging 2007; 22: 8-17.

[35] Hariprasad VR, Koparde V, Sivakumar PT, et al. Randomized clinical trial of yoga-based intervention in residents from elderly homes: effects on cognitive function. Indian J Psychiatry 2013; 55(Suppl 3): S357-S363.

[36] Gothe NP, McAuley E. Yoga and cognition: a meta-analysis of chronic and acute effects. Psychosom Med. 2015; 77: 784-797.

[37] Winett RA, Carpinelli RN. Potential health-related benefits of resistance training. Prev Med. 2001; 33: 503-513.

[38] Chang YK, Huang CJ, Chen KF, et al. Physical activity and working memory in healthy older adults: an ERP study. Psychophysiology 2013; 50: 1174-1182.

[39] Chang YK, Pan CY, Chen FT, et al. Effect of resistance-exercise training on cognitive function in healthy older adults: a review. J Aging Phys Act. 2012; 20: 497-517.
[40] Liu-Ambrose T, Nagamatsu LS, Voss MW, et al. Resistance training and functional plasticity of the aging brain: a 12 -month randomized controlled trial. Neurobiol Aging 2012; 33: 16901698 .

[41] Nagamatsu LS, Handy TC, Hsu CL, et al. Resistance training promotes cognitive and functional brain plasticity in seniors with probable mild cognitive impairment. Arch Intern Med. 2012; 172: 666-668

[42] Leritz EC, Salat DH, Milberg WP, et al. Variation in blood pressure is associated with white matter microstructure but not cognition in African Americans. Neuropsychology 2010; 24: 199208.

[43] Whitmer RA, Sidney S, Selby J, et al. Midlife cardiovascular risk factors and risk of dementia in late life. Neurology 2005; 64: 277-281.

[44] Raji CA, Ho AJ, Parikshak NN, et al. Brain structure and obesity. Hum Brain Mapp. 2010; 31: 353-364.

[45] Verstynen TD, Weinstein A, Erickson KI, et al. Competing physiological pathways link individual differences in weight and abdominal adiposity to white matter microstructure. Neuroimage 2013; 79: 129-137.

[46] McFadden KL, Cornier MA, Melanson EL, et al. Effects of exercise on resting-state default mode and salience network activity in overweight/obese adults. Neuroreport 2013; 24: 866-871.

[47] Zsoldos M, Pajor A, Pusztafalvi H. Relation between sexual dysfunction and metabolic syndrome. [A szexuális funkciózavar és a metabolikus szindróma kapcsolata.] Orv Hetil. 2019; 160: 98103. [Hungarian]

[48] Onyewuenyi IC, Muldoon MF, Christie IC, et al. Basal ganglia morphology links the metabolic syndrome and depressive symptoms. Physiol Behav. 2014; 123: 214-222.

[49] Yates KF, Sweat V, Yau PL, et al. Impact of metabolic syndrome on cognition and brain: a selected review of the literature. Arterioscler Thromb Vasc Biol. 2012; 32: 2060-2067.

[50] Alpert PT, Miller SK, Wallmann H, et al. The effect of modified jazz dance on balance, cognition, and mood in older adults. J Am Acad Nurse Pract. 2009; 21: 108-115.

[51] Fong DY, Chi LK, Li F, et al. The benefits of endurance exercise and Tai Chi Chuan for the task-switching aspect of executive function in older adults: an ERP study. Front Aging Neurosci. 2014; 6: 295 .

(Fábián Balázs dr., Debrecen, Nagyerdei krt. 98., 4032) e-mail: fabian.balazs@sph.unideb.hu)

A cikk a Creative Commons Attribution 4.0 International License (https://creativecommons.org/licenses/by/4.0/) feltételei szerint publikált Open Access közlemény, melynek szellemében a cikk bármilyen médiumban szabadon felhasználható, megosztható és újraközölhető, feltéve, hogy az eredeti szerzỏ és a közlés helye, illetve a CC License linkje és az esetlegesen végrehajtott módositások feltüntetésre kerülnek. (SID_1) 